\title{
Nostalgic Utopianism: The New Zealand Values Party's 1972 Blueprint
}

\begin{abstract}
Although the manifestos or policies of most New Zealand political parties aspire to improve some aspect of the country, few have matched the Values Party's 1972 Blueprint for the utopian form and extent of the changes it promised to being into effect. And unlike the policies of most other New Zealand political parties in the twentieth century, the Values Party proposed that material progress ought to be stopped at some point, echoing the notion of the stationary state which John Stuart Mill devised in 1848. However, the Blueprint's distinctly utopian orientation was not only necessarily subversive of the political status quo in the country, but simultaneously rejected the past and present in favour of a radically transformed future, while (seemingly paradoxically) drawing on a nostalgic interpretation of aspects of New Zealand's colonial era as a thematic source of its utopian construct for the country. This article examines these dimensions of the Blueprint, and how the inherent flaws in practically all utopian movements similarly undermined the Values Party's programme for a utopian New Zealand.
\end{abstract}

\section{Keywords:}

Nostalgia, utopia, environmentalism, Values Party, Mill, manifesto 


\section{Introduction}

The history of utopianism is also a history of the failure of utopian visions to materialise. Yet, rather than the long inventory of these unfulfilled aspirations deterring utopian thinkers, it sometimes has the opposite effect - inciting even more ambitious or vigorously-pursued conceptions of an ideal society. As the French philosopher Henri Lefebvre observed, regardless of the fact that the very idea of utopianism has been discredited, the urge to rehabilitate it recurs on the basis that it is 'indispensable to stimulate change'.1 In the case of the New Zealand Values Party during the 1970s, its environmental utopianism - the core of its weltanschauung - contained elements that typified those of previous utopian movements, 2 and that were destined for a similar fate, but that were nonetheless persisted with because of the dramatic change they promised.

This paper surveys the policies in the Values Party's 1972 manifesto: the Blueprint, 3 and examines how they reflected the utopian aspects if John Stuart Mill's notion of the stationary state (1848); how they were inherently subversive; and how they would ultimately be unachievable without the application ironically - of dystopian measures to enforce their introduction and implementation. The other aspect of the Blueprint that is explored here is the way in which the party's utopian goals were as much a re-imaging of a nostalgic view of New Zealand, as they were a rejection of what had gone before in the country's history. Nostalgia and utopianism in this context emerge more as two sides of the same coin than as distinct and rival notions.

The environmentalism at the heart of the Values Party's utopian programme remained a theme in New Zealand's national politics long after the demise of the party itself appearing subsequently in an attenuated form in the policies of other parties. However, these policies tended to lack the distinctly utopian (or at least eutopian) 4 context that characterised their promulgation in the Blueprint, and similarly were neither subversive nor absolutist in their scope or intent. 


\section{The Utopian Basis of the Values Party's 1972 Blueprint}

Although New Zealand had to contend with various environmental issues during the 1960s, these in themselves did not lead directly to the emergence of the Values Party.5 Rather, it was the more general philosophical approach to the environment by the country's two main political parties in this era (the National and Labour parties), which resulted in the formation of New Zealand's first environmental party. From the perspective of the Party's founders, the two main existing parties in the country - National and Labour - had an allegedly 'technocentric' approach to environmental issues, which was based on the belief that a constantly growing economy, together with continual technological and scientific developments, would meet the needs of the population in a manner that would enable any environmental problems to be 'managed'.6

The Values Party came into being as much as a reaction to such a socio-political philosophy as for any specific environmental issue of the moment. In a speech delivered at the time of the Party's inception, one of its founders, Tony Brunt, was critical of what he considered to be an overemphasis on 'economic growth, technological advance, the importance of consumer goods in our lives, increasing productivity, competition between people, individualism and increasing profits'. Instead, he stressed the importance of meeting 'the needs of people and not the needs of the system'.7 These views were articulated in much greater detail in the Party's Blueprint, which was published in May 1972 - just six months before the country's general election, in which the Values Party received 27,467 votes, or 1.96 per cent of all the votes cast. 8

The Party's Blueprint - essentially a manifesto - was especially broad in scope, addressing the economy, foreign policy, trade, crime, social welfare, technology, and national demographics. One of the more salient features of the Values Party's approach to these areas was that rather than merely 
promising to adjust existing policy settings, they proposed a much more utopian alternative. Before going through the specific polices that illustrate this utopian ambition, though, it is worthwhile at this juncture surveying briefly the main tenets of and challenges to utopianism.

The notion of utopia centres around a future that approximates perfection. While the premise had existed in the classical world, 9 it entered the popular imagination in Europe in the sixteenth century (the term 'utopia' was coined by Thomas More),10 where it offered an earthly antidote to the difficulties of people's lives11 (as they waited for the utopia of heaven after death). The age of discovery accelerated interest in the possibility of utopias existing in parts of the world as yet unknown to Europe, with the idea of the 'noble savage' gaining currency among some European philosophers.12 By the late 1700s, utopianism had become 'a way of thinking', a philosophical attitude', or sometimes even an allegory of freedom 13 more so than a quest for a physical location of perfection, 14 but during the nineteenth century, cynicism about the possibility of achieving a utopia had set in. The historian Thomas Babington Macaulay suggested that ' $\mathrm{t}]$ he smallest actual good is better than the most magnificent promises of impossibilities'.15 And as the philosopher Herbert Spencer noted in the case of republicanism, while it may have been the 'highest form of government', it required 'the highest type of human nature - a type nowhere at present existing'.16

Despite these doubts over utopianism's efficacy, utopian theories continued to be promulgated in the nineteenth century, ranging from Jeremy Bentham's advocacy of the paramountcy of utilitarianism, 17 through to Karl Marx's conception of a future world where the means of production would be redistributed, and where the divisions of wealth, class, and nation states would no longer exist.18 The possibility that a better world something approaching a heaven on earth19 - could be brought about in a more rapid and drastic fashion (rather than through a more gradual and evolutionary process) was a key element of 
nineteenth century utopian philosophies, 20 and was a theme that persisted in utopian programmes in the twentieth century. 21

The Values Party's Blueprint, while not calling for a violent overthrow of the New Zealand government, nonetheless advanced a revolutionary programme, in so far as it advocated for a rejection of substantial elements of the country's existing political, social, and economic system in favour of a dramatically new social, economic and philosophical approach to running New Zealand.

There were several policies in particular in the Blueprint that promised both a dramatic departure from the existing approach in New Zealand to these issues, and the prospect of a utopian future if they were adopted. One of the overarching aims of the party - and one which informed many of its subsequent policies - was the intention to achieve zero population growth. The rationale for this approach was that it would protect the environment, prevent urban growth, and minimise social change, which was deemed to be inherently psychologically harmful.22 One of the corollaries to having no population increase was the opportunity that the Values Party sought to limit and possibly even halt economic development, on the basis that this would allow for increased leisure time for workers, reduce inflation, and overcome what it disparagingly referred to as the 'growth syndrome', in which economic growth had become an end in itself. 23

Even more radical was the suspicion with which the Values Party viewed technological development. The Blueprint anticipated a society where controls on new technology would be imposed because unfettered technological advances were regarded as 'dehumanising' and supposedly threatened to destroy humanity.24 Consumerism was similarly attacked because of the belief that it led to the unnecessary consumption of resources. To assist with reining in production, strict curbs would be imposed on advertising, which was depicted as being 'at war' with the environment and society.25 And as a further 
measure to protect the environment, the number of cars would be limited, as would the height of buildings to increase the 'attractiveness' of suburbs (and town planners would undergo re-training to enable them to see the merits of this policy).26

In penal policy, the Blueprint proposed that most prisons be closed, that most prisoners released into forms of rehabilitation in the community, and that for those remaining in confinement, they would have comfortable cells and even be allowed alcohol to drink, so as not to alienate them from their former lives.27

And in keeping with the desire to achieve and maintain zero population growth, the Values Party would subsidise contraception, make abortions readily available, and even require the state to sterilise men and woman (at their request).28 Through such measures, the state would be able to assist with controlling not only population size but also rates of resourceconsumption.

Considered collectively, these and other policies in the Blueprint offered voters in the 1972 General Election a vision of a radically transformed country, with many of the social, economic, and even aesthetic norms at threat of being overturned. The Values Party's leaders, if they ever came to power, would revolutionise the way New Zealand was run, the values under which it functioned, and thereby usher in a utopian alternative to the existing nature of the country's society and economy. Yet, for all its apparent newness, the idea of restraining growth in various parts of the economy and society had its philosophical antecedent in the nineteenthcentury work of the English social philosopher, John Stuart Mill.

\section{Echoes of Mill's Stationary State in the Blueprint}

There are various dimensions to utopianism, but one that seldom gets mentioned in analyses of the concept is John Stuart Mill's notion of the stationary state (1848). In part because of its economic orientation, the Stationary State generally tends to 
be the focus of principally of economists. However, Mill also espoused elements of the Stationary State that are distinctly utopian in nature, and that have a bearing on the utopian model for New Zealand that the Values Party devised in 1972.

It is possible that the mirroring of Mill's utopian position on the Stationary State in the Values Party's Blueprint was coincidental, but the relationship between the two is so close in parts that it at least suggests (admittedly without any firmer evidence) that the former had some influence on the latter. Certainly, much of Mill's writings shaped the nature of twentieth-century socialism,29 which in turn the Values Party was ideologically connected with to some extent, 30 (although it was not slavishly bound to socialist doctrine, as its leaders emphasised).31 There are three aspects of Mill's Stationary State that have a strong resonance with the utopian elements in the Values Party's Blueprint. These are: the need to restrict economic growth; the need to limit increases in population; and the risks of technological advances.

Mill's anxiety over the pursuit of economic growth and wealth for its own sake was central to his analysis of the principles of political economy. He cautioned that 'the increase of wealth is not boundless', and that instead of the ceaseless pursuit of economic progress (that he believed would become ever more challenging as it was dependent on an infinite supply of resources), he prescribed a 'stationary state'. In such a state, there would be 'a suspension of the overflow of capital from those countries [which had ceased their constant accumulation of capital] into the uncultivated or ill-cultivated regions of the earth'.32 Once free from the perpetual pursuit of economic growth, societies would be free to turn their attention to cultural and education improvement among their populations. Mill foresaw in this stationary state that there would be 'as much scope as ever for all kinds of mental culture, and moral and social progress; as much room for improving the Art of Living, and much more likelihood of its being improved, when minds ceased to be engrossed by the art of getting on'.з3 His utopian 
vision of a state that was sufficiently prosperous to fund social and intellectual improvement without being captured by the need constantly to generate additional wealth was echoed in the Values Party's Blueprint, with its suspicion of economic growth for its own sake, and its view that the economic growth could be restrained and even halted so that the economy served the needs of the people, and not vice versa.34

On the topic of population growth, Mill (possibly taking a cue from Malthus)35 was concerned by significant population increases, even in those countries that still had the space and means to accommodate them. A country, he suggested,

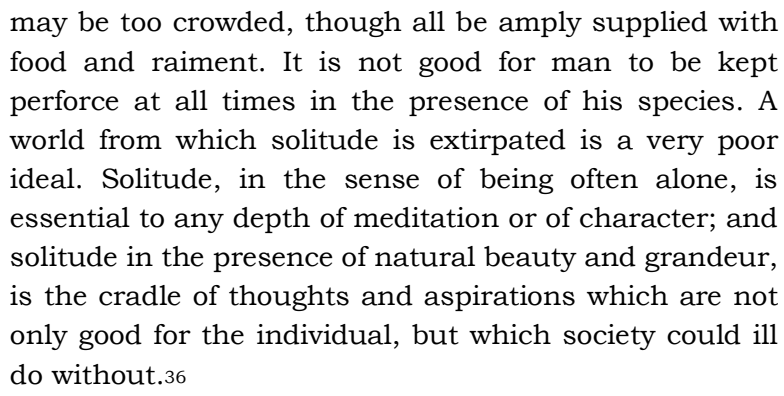

The sense of an Arcadian utopia that is evident in this portion of Mill's construction of the ideal stationary state - in which a country's population was able to enjoy the natural world in solitude - has a strong parallel in the Blueprint. The Values Party was committed to achieving zero population growth, and for the similar reasons of enhancing the psychological welfare of the population, maintaining the aesthetic appeal of the landscape, and affording workers more leisure time, including being able to spend time alone in nature.37

It was in the realm of technological development, though, where the correlation between Mill's utopian stationary state and the policies of the Values Party contained in the Blueprint was most pronounced. Writing at the peak of the Industrial Revolution, Mill questioned if all the mechanical inventions yet 
made have lightened the day's toil of any human being', or whether they had instead simply ensnared more of the population in 'the same life of drudgery and imprisonment'. In 1848, Mill observed that technology had yet to produce any improvements in 'human destiny', and should not be regarded as the means 'of improving and elevating the universal lot'.38 Such cynicism about the potential for technology to transform society for the better matched the sort of distrust the Values Party had in the contribution of technology to social improvements 124 years later. In both cases, technology was perceived as much an obstacle to as a means of achieving a utopian future. The Blueprint described technology generally as 'dehumanising' and if not restrained, the Values Party believed that technology would increasingly impair rather than enhance humanity.39

In these three policy areas - economic growth, population growth, and technological development - as well as others to a lesser extent, Mill's utopian conception of a stationary state was the philosophical progenitor of the utopian policies of the Values Party as expressed in its 1972 Blueprint. Not only did both Mill and the Values Party approach these policies from a close philosophical standpoint, but both developed their closelyrelated positions on these policy areas with a view to contributing to a utopian future - one which was radically different from the trajectory most people in both eras felt was expected for society.

\section{The Nostalgic Core in the Blueprint}

Although utopian policies tend to promise a radically improved future in part by shedding the imperfections of the present, there is a paradox at the heart of utopianism: that its only terms of reference for such improvement are found in the past - either as models to be resurrected or examples to be avoided. The Values Party's Blueprint to some extent conformed to this tendency to look to history to seek better forms of social 
organisation and then appropriate these as idealised models to restore society from some of the deficiencies of the present. But while the past was instructive, at the same time it was also riddled with the sort of shortcomings in societies and individuals that the utopian constructs, such as those contained in the Blueprint, promised to remedy.40 What therefore emerged was a highly selective revival - and even fetishizing 41 - of elements of the past as motifs for the utopian future that the Party's leaders were constructing. In some ways, such longings for utopia and nostalgia are identical yearnings, 42 both of which idealise a stylised construction of a period - either one which has been or one that is anticipated.

There are certainly several policies in the Blueprint which, while not making any explicit association with a specific period of the past, nonetheless could be construed as drawing on a nostalgic interpretation of aspects of New Zealand's colonial era (particularly the latter decades of the nineteenth century) as a model from which a utopian future could be shaped. In this context, such nostalgia depends on both a shared forgetting of history and a shared selectivity in its recollection. 43 It is precisely the absence of any application of rigorous historical method that makes the material of the past malleable enough to be re-moulded into a utopian form. People are inclined to make this altered past part of themselves, and in turn, make themselves part of that past.44 In the case of the Values Party's Blueprint, the policies on population, technology, and especially the environment all seemed to draw on elements of a nostalgic impression of colonial New Zealand as a template for the utopian future of the country.

In the case of the party's population policy, the emphasis on zero population growth contained allusions to the recovery of aspects of a nostalgic past in the country, when the population was substantially lower than it was in the early 1970s, and when there was a focus on agricultural rather than industrial production. As examples, large cities were castigated in the Blueprint as centres of social problems, a 'spacious habitat' that 
could only be maintained by zero population growth was seen as important to producing a 'kind' society, and in a nod to a nostalgic view of an earlier, more bucolic period in the country's history, the point was made that as populations grew, 'cities spread into what was once familiar countryside', making it that much harder to retrieve the 'stable societies of a bygone age'. The past, at least in population terms, was a preferable place to the present.45

Technological development was another policy area in the Blueprint where traces of nostalgia are detectable. Some of the text comes across almost as a lament for the passing of an age where technology was a less prominent feature in people's lives. In the following passage, reference to a preferable past is explicit as the case is made for the harm associated with increasing levels of technology in society: "The spread and availability of cars has made young people more mobile and [has] tended to cut down on communication in families'. This fondness for an age when there were fewer vehicles could refer to just a generation or two earlier, but the following segment suggests that the ideal period on which the Values Party's utopian technological policy was built more likely lay somewhere in nineteenth-century New Zealand. The authors of the Blueprint expressed the anxiety that cars cut people off from nature, and that New Zealanders in the car age (effectively the twentieth century) 'spend spare time tinkering with crankcases rather than weeding the garden and planting vegetables and flowers'. The implicit suggestion of a return to a better way of living, in which cars barely featured, was clearly a nostalgic strain in this section of the Blueprint. In a similar vein, television was condemned to a large extent because it introduced programmes which 'bulldoze our habits and values'. Again, at the core of this utopian promise to restrict the rate of technological advancement was a reactionary strain which sought to revive 'habits and values' which had supposedly existed prior to the introduction of television into the country.46 
It was in the set of policies relating to the environment, though, where the Blueprint seemed closest to producing a prescription for a return to a nineteenth-century notion of New Zealand.47 The Values Party wanted, for example, to restore grassed areas in inner-city precincts, and banish cars from them; and the great age of trains, in the 1800 s, would be revived for the latter twentieth century as a preferred mode of transport.48 Tall buildings became a target of the Blueprint's authors, as they were said to 'disturb the skyline'. The Party favoured a return to smaller buildings, of the sort which dominated New Zealand in the colonial era, and in a more direct nostalgic appeal, the Party committed itself to promoting the preservation of older buildings and public amenities in New Zealand cities in order to preserve the character of the cities and protect them from "progress"'.49 This was an overt appeal to a time in the country's history in which its buildings were deemed to be aesthetically preferable to the present. Likewise, the Blueprint advocated that streets be narrower in order to "bring houses closer together and...foster an atmosphere of intimacy instead of isolation'.50 Again, this was suggestive of a return to the sort of suburban landscapes that were much more common in New Zealand in the latter nineteenth century.51

When considered in combination, these policy areas all tilted in various ways towards an idealised (albeit vague) conceptualisation of late colonial-era New Zealand. The less congested, less urbanised, less developed, less technological, and more supposedly socially integrated society of the country in the nineteenth century - however generalised and sentimental these nostalgic perceptions were - provided ample scope and inspiration for the utopian vision of a future New Zealand society contained in the Blueprint.

\section{Deficiencies with the Blueprint's Utopianism}

The Blueprint was more, however, than an unwitting revival of a nineteenth-century utopian social philosophy, and a utopian 
vision inspired in parts by a desire to recover what looked to be an irretrievable nostalgic past. Moreover, it did not contain policies that aimed merely modify those of the existing political parties in New Zealand in the early 1970s. Rather, the utopian elements in the Blueprint were at their core subversive, in so far as they rejected not only policies of governments of the era, but even the prevailing government, social and economic structures themselves. However, because radically new systems of society, government, and the economy would be a prerequisite for the Values Party's utopian ideal, the severe disruption along path towards this ideal would potentially put at risk elements of the Blueprint which formed the basis of the revolution in the first place. The process of achieving this utopia would thus (ironically) jeopardise at least some of the elements of that utopian vision.

The Values Party's prescription for a utopian future for New Zealand would involve what Karl Popper warned of as 'utopian engineering'.52 In reconstructing society in the image outlined in the Blueprint, there would necessarily be substantial upheaval over a substantial length of times3 - something that is inherently counter to the notion of utopia. And during such a process of disruption, Popper observed that reasonable criticism of the adjustments occurring in the society would have to be suppressed so as not to derail progress to the utopian alternative.54 Both the need for and means of suppression would be fundamentally dystopian. As Dahrendorf noted, "[o]ne of the basic assumptions of all utopian constructions is that conditions may be created under which conflicts become superfluous....But in reality these conditions do not exist. In fact, with the terrible dialectics of the non-rational, it happens that utopia first requires and then glorifies suppression'. 55

The process of transition to a utopian society was where Popper identified some of the greatest threats to utopian ideals themselves would germinate. The transition would be 'a time of revolutions, both political and spiritual, and of new experiments and experience in the political field. It is therefore to be expected 
that ideas and ideals will change'.56 It would be naïve to believe that the utopian visions necessitating a subversive or revolutionary process would remain unaffected by such momentous changes.

Another deficiency with the nature of utopian conceptions of the future is that they tend to be fixed. This is evident in the Blueprint, which contains details on the policy framework that would support a future utopian New Zealand, but gives no clear indication of the means by which this utopian conception could be amended. The absence of a system for modification of utopian ideals in documents such as the Blueprint is understandable, in that if the prescription of the utopian future is perceived to be the ideal, then any modifications would only serve to lessen or even undermine that ideal. And if there was some rational system put in place to allow for modifications, then this would undermine any claims of the utopian nature of the proposed changes such as those contained in the Blueprint. Instead, the policies would be more utopian-oriented rather than strictly utopian.

There is also a presumption in documents such as the Blueprint that the consequences of the processes involved in reaching the utopian society can be calculated in advance. However, there is bound to be insufficient knowledge of the consequences of a transition to a utopian society to enable such calculations to be made.57 In the absence of sufficient knowledge of the nature and consequences of the transition to a utopian end, Popper warned that there would be 'a dangerous and dogmatic attachment to a blueprint', which would defy rationality. In practice, this would reduce the process of reaching a utopian society to one of trial and error. What improvements might be achieved would be at the expense of the mistakes that precede them, and the process of making modifications to rectify mistakes would still remain unscientific in so far as the consequences of such rectifications would remain unknown, with only their function as a remedy for a mistake being measurable as opposed to achieving the 
originally-stated utopian goal. The question then emerges of how can the claim that a process is advancing toward a utopian end be upheld when those responsible for that process are unable to anticipate the consequences of each stage in the process. 58

Another aspect of the Blueprint which subverts its utopian goals is its failure to contend with the implications of New Zealand being a multicultural society. Admittedly, the Values Party did have a policy on Maori, in which it recommended that ' $\mathrm{t}$ ] he task ahead is not to assimilate the Maori but to foster his racial and cultural identity'.59 However, there can be a 'jarring of meanings and values generated in the process of cultural interpretation,' in which the interests of cultural minorities in a state can be subverted.60 There is no evidence that the Values Party considered the interpretation of its utopian objectives through anything other than a contemporary European lens, and there is an implicit presumption throughout the Blueprint that the utopian nature of certain policies somehow made them universal, and thus would transcend any differing cultural perspectives of them. Indeed, even among the country's European population, there was no homogeneity, and so the expectation that there could have been a uniform comprehension of the Blueprint's utopian tenets is far from certain.61 The absence of such uniformity in understanding of the nature of the proposed utopia was another factor undermining the utopian aspects of the Blueprint.

The attitude towards technology evident in the Blueprint is another facet of the Values Party's policies that corrupted its utopian ideal. Technology was portrayed as something that works against the interests of society and therefore needs to be reined in. this stance might have been as much if not more a reaction to the accelerating rates of technological change that had been experienced in the preceding decades than as means of achieving an improved future.62 Because technological advancement was not necessarily able to be harnessed exclusively for the benefit of any single utopian construct, its 
presence served as a variable that potentially threatened the certainty of the Values Party's prescription for a utopian future. The desire in the Blueprint for a technologically settled, stationary state, was at odds with the disruptive and dynamic nature of technological progress,63 and so had to be contained as much as possible so as not to upset all the other utopian components of the Blueprint. This discomfort with dynamism was one of the features of that group of utopian thinkers during the French Revolution who favoured a static form of utopia that would only require fine-tuning to maintain its goal,64 and had permeated the thinking of the Blueprint's authors.

Ultimately, the appeal of a utopian future tends to be predominately emotional,65 but any attempt to achieve it requires reason.66 However, the dependence on reason cannot advance the utopian goal very far at all as long as there remains too little information to calculate the effects of the process of achieving the utopia, and as long as there are differing cultural interpretations of the form of the utopia. This remains the insurmountable flaw with the Blueprint. It identifies policies that its authors believed would achieve a utopian society in New Zealand without addressing in any substantive way the counteractive and even dystopian route by which the utopian end would be reached. And even if that end could somehow be achieved, there was no mechanism identified by the Values Party's policy-makers for modification of the Blueprint, which implied that they believed it could withstand changes in society, technology, culture, technology, and other variables which are responsible for social evolution.

Perhaps nothing undermines utopian constructs - such as that contained in the Blueprint - more than the fact that they rely on changing the nature, values, and expectations of people in order to make the proposed utopias viable. This notion of the 'perfectibility of humankind' 67 requires a negation of reality, 68 and therefore renders such utopian projects little more than speculative exercises that cannot be enacted as long as they ignore the impossibility to accomplish such revolutionary 
changes in an entire society. To a large degree, the utopian elements of the Blueprint fall into this category. Engineering social change, preventing population growth, and holding back economic growth and technological progress - which were among the key tenets of the Blueprint - were inherently unrealistic (at least in the context of the preceding several centuries of human history). John Gray's succinct critique of environmental-based utopian manifestos encapsulates neatly the unattainability of the utopian policies in programmes such as the Values Party's Blueprint:

\begin{abstract}
a high-technology green utopia, in which a few humans live happily in balance with the rest of life, is scientifically feasible; but it is humanly unimaginable....There is only one way humanity can limit its labours, and that is by limiting its numbers....Zero population growth could be enforced only by a global authority with draconian powers and unwavering determination. There has never been such a power and there never will be.69
\end{abstract}

The futility of the Blueprint's utopian programme was precisely that it was only achievable through the application of draconian authority, which immediately would invalidate its utopian pretensions.

\title{
Conclusion
}

The Blueprint that the Values Party devised in 1972 promised a radical transformation of New Zealand with the aim of achieving a utopian future for the country. Consciously or otherwise, the theme of reaching a stationary state - of the sort conceived by Mill - was a pronounced feature of this utopian construct. However, the path towards that goal was not so much evolutionary (in the way Mill imagined it would be) but essentially subversive of the status quo as far as New Zealand's approach to areas such as technology, population growth, economic growth, foreign policy, law and order, social policy and 
other areas of national policy. Yet, for all its apparent radicalism, some aspects of the Values Party's utopian vision involved re-casting a nostalgic interpretation of New Zealand's colonial era into an ideal for the future. This represents a paradox, with the Blueprint both implicitly rejecting the past as inadequate and even destructive, but at the same time drawing on elements of that nostalgically-interpreted past as inspiration for its utopian programme. More generally, this highlights the symbiotic relationship between nostalgia and utopianism, in which nostalgia simultaneously informs models of utopia yet is the object of repudiation by those crafting their utopian model for the future.

Although never implemented, the Blueprint's utopian policies shared the same essential flaws of most other utopian visions: that they would require some form of coercion of the population in order for the utopia to be realised (which would undermine the essence of the utopian society); and that the utopian model presented by the Values Party was a static one. The absence of any significant room for the amendment of the goals implied that they were the best of all possible goals and were imperative in order to reach the utopian state. However, static goals require, at the very least, static societies, unchanging technologies, and the absence of new ideas - traits that have been defied by all major societies over time.70 Had any attempt subsequently been made to implement the Blueprint, these deficiencies would have debilitated its utopian aspirations, and rendered it less revolutionary and less visionary in the process.

While the strong environmentalism that underpinned the Blueprint's utopianism eventually filtered through to other more mainstream New Zealand political parties in the following decades, their utopian elements were removed, and they appeared in much more diluted forms in the process. Social evolution trumped a social and moral revolution, and the absence of a utopian strain to some of these later policies also emancipated them from any strong nostalgic ties, of the sort 
which bridled so much of the Values Party's utopianism, while also freeing them to ongoing adjustments and improvements to accommodate the perpetual changes in the society for which they were intended. 


\section{Notes}

1 Henri Lefebvre, in Andrew Merrifield, Henri Lefebvre: A Critical Introduction (Routledge: New York, 2006), 163.

2 Lucy Sargisson and Lyman T. Sargent, Living in Utopia: New Zealand's Intentional Communities (Aldershot: Ashgate, 2004), 1516.

3 New Zealand Values Party, Blueprint for New Zealand: An Alternative Future (New Zealand Values Party: Wellington, 1972).

4 Gregory Claeys and Lyman T. Sargent, The Utopia Reader (New York: New York University Press, 1999), 1.

$5 \quad$ Christine R. Dann, From Earth's Last Islands: The Global Origins of Green Politics, PhD thesis (Christchurch: Lincoln University, 1999), 251-2.

$6 \quad$ Ton Bührs, Working Within the Limits: The Role of the Commission for the Environment in Environmental Policy Development in New Zealand, PhD thesis, (Auckland: University of Auckland, 1991), 723.

7 Tony Brunt (1972) in Dann, 257.

8 Nigel S. Roberts, 'Trans-Tasman twins: The 1972 general elections in Australia and New Zealand,' The Journal of the Australasian Political Studies Association 8.1 (1973):148-9.

9 David Lloyd, 'Francois le Vaillant and the myth of the noble savage: a Frenchman in eighteenth-century Southern Africa,' Scrutiny2 9.2 (2004): 53-4; Gaius Tacitus, The Agricula and Germania, Richard B. Townshend (trans.), (London: Methuen and Co.,1894), 54-98.

10 Thomas More, Libellus vere aureus, nec minus salutaris quam festivus, de optimo rei publicae statu deque nova insula Utopia (Louvain: Thierry Martens, 1516); Its English title was On the Best State of a Republic and on the New Island of Utopia, Concerning the Highest State of the Republic and the New Island Utopia.

11 Lyman T. Sargent, Utopianism: A Very Short Introduction (Oxford: Oxford University Press, 2010), 4; Ruth Levitas, The Concept of Utopia (Bern: Peter Lang AG, 2010), 2.

12 Victor Gourevitch, 'Nothing in Rousseau's account of men in the pre-political state of nature justifies calling them 'noble savages"', in Victor Gourevitch (ed.), Rousseau: The Discourses and Other Early Political Writings (Cambridge: Cambridge University Press, 2004), xxi; William Robertson, The History of the Discovery and Settlement of America (New York: J \& J Harper, 1831), 140; Henry Mackenzie, The Man of the World (London: Robert Tullis, 1802), 254.

13 Stelio Cro, The Noble Savage: Allegory of Freedom (Ontario: Wilfrid Laurier University Press, 1990), 131-150.

14 Leszek Koalkowski, Modernity on Endless Trial (Chicago: University of Chicago Press, 1990), 131.

15 Thomas B. Macaulay, The Works of Lord Macaulay Complete, vol. 6 (New York: Longmans, Green, and Co., 1897), 220. 
16 Herbert Spencer, Essays: Scientific, Political \& Speculative vol. 3 (London: Williams and Norgate, 1891), 478-9.

17 Jeremy Bentham, An Introduction to the Principles of Morals and Legislation (London: W. Pickering, 1823), 35; Mary P Mack, Jeremy Bentham: An Odyssey of Ideas, 1748-1792 (London: Heinemann, 1962), 204.

18 Robert C. Tucker (ed.) The Marx-Engels Reader, Second Edition (New York: W. W Norton and Company, 1978), 474ff.

19 Robert F. Sayre, 'American Myths of Utopia,' College English 31.6 (March 1970): 613.

20 As an example, see Karl Marx, Critique of the Gotha Program, [1875] (Maryland: Wildside Press LLC, 2008), 39.

21 As an example, see Jiping Zuo, 'Political religion: The case of the cultural revolution in China,' Sociology of Religion 52.1 (1991): 99110.

22 New Zealand Values Party, Blueprint, 8.

23 Ibid., 11-12.

24 Ibid., 13.

25 Ibid., 20.

26 Ibid., p. 7.

27 Ibid., p. 44.

28 Ibid., p. 56.

29 William Irvine, 'Shaw, the Fabians, and the Utilitarians', Journal of the History of Ideas 8.2 (1947): 218-231; David M. Ricci, 'Fabian socialism: a theory of rent as exploitation,' The Journal of British Studies 9.1 (1969): 105-121.

$30 \quad$ Dann, 237, 347.

31 Terry McDavitt, 'Beyond Socialism,' Turning Point 1.9 (November/December 1975): 17, in Dann, 358-9.

32 John Stuart Mill, The Collected Works of John Stuart Mill, Volume III - The Principles of Political Economy with Some of Their Applications to Social Philosophy (Books III-V and Appendices), ed. John M. Robson (Toronto: University of Toronto Press, 1965), 226.

33 Mill, 229.

34 Tony Brunt (1972) in Dann, 257.

35 Thomas R. Malthus, An Essay on the Principle of Population (London: J. Johnson, 1803).

36 Mill, 228-9.

37 New Zealand Values Party, Blueprint, 8.

38 Mill, 229.

39 New Zealand Values Party, Blueprint, 13.

40 James C. Davis, Utopia and the Ideal Society: A Study of English Utopian Writing 1516-1700 (Cambridge: Cambridge University Press, 1983), 37, 136, 370, 378.

41 Jon Goss, 'Disquiet on the waterfront: Reflections on nostalgia and utopia in the urban archetypes of festival marketplaces,' Urban Geography 17.3 (1996): 222.

42 Judith Shklar, The political theory of utopia: from melancholy to nostalgia,' Daedalus 94.2 (1965): 378. 
Linda Hutcheon, 'Interventionist literary histories: Nostalgic, pragmatic, or utopian?' Modern Language Quarterly 59.4 (1998): 413-4.

David Lowenthal, The Past is a Foreign Country (Cambridge: Cambridge University Press, 2003), 348.

New Zealand Values Party, Blueprint, 9-10.

Ibid., 14.

The link between environmentalism in New Zealand and the country's 'pioneer' period is discussed in Sargisson and Sargent, Living in Utopia, 114.

New Zealand Values Party, Blueprint, 38.

Ibid., 39-40.

Ibid., 41.

Richard W. Armstrong, 'Auckland by gaslight: An urban geography of 1896,' New Zealand Geographer 15.2 (1959): 173-189.

Karl Popper, The Open Society and its Enemies (Princeton: Princeton University Press, 2013), 147.

Ibid., 150.

Ibid., 150.

Ralph Dahrendorf, Society and Democracy in Germany (New York: Doubleday Anchor, 1967), 139.

Popper, 150.

Ibid., 151.

Ibid., 152, 156-7.

New Zealand Values Party, Blueprint, 49.

Homi K. Bhabha, The Location of Culture (Oxford: Routledge, 1994), 232.

1 Russell Jacoby, The End of Utopia: Politics and Culture in an Age of Apathy (New York: Basic Books, 1999), 60-62.

Mulford Q. Sibley, 'Utopian thought and technology,' American Journal of Political Science 17.2 (1973): 255-281.

Frank E. Manuel and Fritzie P. Manuel, Utopian Thought in the Western World. (Cambridge MA: Harvard University Press, 2009), 448.

Ibid., 566; Barrington Moore Jr., 'Misgivings about Revolution: Robespierre, Carnot, Saint-Just,' French Politics and Society 16.4 (1998): 17-36.

Melvin J. Lasky, Utopia and Revolution: On the Origins of a Metaphor (New Brunswick: Transaction Publishers, 2004), 138.

Kant argued for the primacy of reason over emotion. See Helge Svare, Body and Practice in Kant (Dordrecht: Springer, 2006), 36.

Ruth Levitas, Utopia as Method: The Imaginary Reconstruction of Society (London: Palgrave Macmillan, 2013), chap. 1.

Alexandre Franco da Sa, 'From Modern Utopias to Contemporary Uchronia,' in Patricia Vieira and Michael Marder (eds.), Existential Utopia: New Perspectives on Utopian Thought (New York: Continuum International Publishing Group, 2012), 25

9 John Gray, Straw Dogs: Thoughts on Humans and Other Animals (London: Granta Books, 2002), 184-5. 
70 Durkheim's notion of deviance examines the impetus for change in societies. See Thorolfur Thorlindsson and Jón G. Bernburg, 'Durkheim's theory of social order and deviance: a multi-level test,' European Sociological Review 20.4 (2004): 271-285. 